Urban History Review

Revue d'histoire urbaine

\title{
Thesis Abstracts
}

Résumés des thèses

T.I. Gunton. "Evolution of Urban and Regional Planning in Canada, 1900-1960." Ph.D. Thesis, School of Community and Regional Planning, University of British Columbia, 1981

Elizabeth Bloomfield. "City-building Process in Berlin / Kitchener and Waterloo, 1870-1930." Ph.D. Thesis, Department of History, University of Guelph, 1981

G. Drangushan. "Regional Planning in Alberta: The Evolution of Alberta's System of Regional Planning

Commissions." M.A. Thesis, School of Community and Regional Planning, University of British Columbia, 1979

D. Hinds. "The Evolution of Urban Public Park Design in Europe and America: Vancouver Adaptation to 1913." M.A.

Thesis, School of Community and Regional Planning, University of British Columbia, 1979

S.L. Kelly. "Senior Citizen Housing in Edmonton: A Spatial Perspective." M.A. Thesis, Department of Geography, University of Alberta, 1980

R.G.F. Higgings. "The Role of the State in the Development of Town Planning in England, 1875-1909." M.A. Thesis, Department of Geography, University of Alberta, 1980

Sara D.S. Gibson, "Sense of Place - Defence of Place: A Case Study of the Toronto Island." Ph.D. Thesis, Department of Geography, University of Toronto, 1981

Irene E. Robertson. "The Business Community and the Development of Victoria, 1858-1900." M.A. Thesis,

Department of History, University of Victoria, 1981

Volume 11, numéro 1, june 1982

URI : https://id.erudit.org/iderudit/1019074ar

DOI : https://doi.org/10.7202/1019074ar

Aller au sommaire du numéro

Éditeur(s)

Urban History Review / Revue d'histoire urbaine

ISSN

0703-0428 (imprimé)

1918-5138 (numérique)

Découvrir la revue

Citer ce document

(1982). Thesis Abstracts / T.I. Gunton. "Evolution of Urban and Regional Planning in Canada, 1900-1960." Ph.D. Thesis, School of Community and Regional Planning, University of British Columbia, 1981 / Elizabeth Bloomfield. "City-building Process in Berlin / Kitchener and Waterloo, 1870-1930." Ph.D. Thesis, Department of History, University of Guelph, 1981 / G. Drangushan. "Regional Planning in Alberta: The

Evolution of Alberta's System of Regional Planning Commissions." M.A. Thesis, School of Community and Regional Planning, University of British Columbia, 1979 / D. Hinds. "The Evolution of Urban Public Park Design in Europe and America: Vancouver Adaptation to 1913." M.A. Thesis, School of Community and Regional Planning, University of British Columbia, 1979 / S.L. Kelly. "Senior Citizen Housing in Edmonton: A Spatial Perspective." M.A. Thesis, Department of Geography, University of Alberta, 1980 / R.G.F. Higgings. "The Role of the State in the Development of Town Planning in England, 1875-1909." M.A. Thesis, Department of Geography, University of Alberta, 1980 / Sara D.S. Gibson, "Sense of Place - Defence of Place: A Case Study of the Toronto Island." Ph.D. Thesis, Department of Geography, University of Toronto, 1981 / Irene E. Robertson. "The Business

Community and the Development of Victoria, 1858-1900." M.A. Thesis, Department of History, University of Victoria, 1981. Urban History Review / Revue d'histoire urbaine,

11(1), 67-71. https://doi.org/10.7202/1019074ar

Ce document est protégé par la loi sur le droit d'auteur. L'utilisation des services d'Érudit (y compris la reproduction) est assujettie à sa politique d'utilisation que vous pouvez consulter en ligne.

https://apropos.erudit.org/fr/usagers/politique-dutilisation/ 


\section{Thesis Abstracts/Résumés des thèses}

T.I. Gunton. "Evolution of Urban and Regional Planning in Canada, 1900-1960." Ph.D. Thesis, School of Community and Regional Planning, University of British Columbia, 1981.

Urban and regional planning is now accepted as a legitimate function of government. But the evolution of Canadian planning from its inception at the turn of the century to its new-found status as an objective technical exercise has been a profoundly complex process involving questions about the very nature of society. This thesis is an attempt to trace the development of the theory and practice of planning from its controversial beginnings at the turn of the century to its final acceptance as a necessary and desirable function of the state.

At the beginning of the century it became clear that the rapid pace of urbanization and the capitalist institutions of private property and unregulated private markets were in serious conflict. The new urban, industrial order that accompanied capital accumulation was plagued by interdependencies and interactions which made the unrestricted use of property an antiquated and dangerous illusion threatening the physical health of the population, the efficiency of the urban system, and the social stability of the entire society.

Canadians responded to this conflict in three distinct and somewhat contradictory ways. One approach which was advocated by agrarian radicals was to implement reforms in Canadian society in order to revitalize rural live and reverse the undesirable trend of urbanization. The second approach, which was advocated by urban liberals, was to accept urbanization as both desirable and inexorable and to accommodate it by initiating limited reforms while still preserving the basic features of capitalism. The third response, advocated by urban radicals, was to accept urbanization as inexorable and to restructure capitalist institutions which were inimical to the sorts of government planning they thought was necessary to manage the new urban order.

Urban and regional planning was considered as essential by all these groups. After going through several initial stages of development, a comprehensive body of planning theory which appealed to all three groups was formulated by leading Canadian planners such as Thomas Adams. This theory integrated the aesthetic concerns of city beautiful planning, the efficiency concerns of American city planning, and the equity concerns of British town planning. The theory envisaged a strong role for the state in controlling property and providing housing.
By the twenties, the consensus that had formed around this theory of planning collapsed due to a gradual ameliora ion of urban problems and an overt confrontation between liberals and urban and agrarian radicals. During the twenties a new, more conservative theory of planning developed which emphasized the protection of private property and the provision of public infrastructure to accommodate private accumulation. Planners became allied with real estate interests who were eager to use zoning and other powers of the state to their advantage.

With the collapse of the economy in the thirties, the latent ideological conflicts which had been submerged in the twenties reappeared with renewed vitality. The urban and agrarian radicals joined forces to form a socialist party dedicated to eradicating capitalism and replacing it with a planned economy. Liberals were forced to formulate a new system of both managing the crisis and preserving capitalism. Gradually they developed a new consensus that was based on the three principles of Keynesian stabilization policies, social welfare and sectoral planning for those areas of the economy plagued by market failures.

Housing and land were defined as one of the sectors of the economy affected by market failures. Major government reports defined a new post-war system of urban and regional planning to mitigate these failures in land and housing markets. The reports were highly critical of the type of planning existing in the twenties and proposed a new, more comprehensive system of planning and of controls over property.

The urban liberals, however, who were the dominant group, were apprehensive about the increased role of the state envisaged in these reports. Consequently, they only partially implemented the recommended reforms. Urban and regional planning, although strengthened, was ultimately subordinated to the interests of private markets and property. It again became a passive system of regulation, providing necessary services to accommodate private expansion and regulations to enhance property rights. Nonetheless, its strengthened position ensured that the worst features of development were eliminated.

The tendency of liberal planning to shift back and forth between more aggressive intervention during times of crisis and very passive intervention during times of stability has meant that, because of the long lag times between the emergence of crisis and the creation of plans and institutions capable of managing the crisis, Canadian planning has been strongest after the crisis has already subsided or when it has changed form. Consequently, the ability to 
plan has been highest when the need to plan has been lowest.

One question raised by the thesis is why the more passive liberal approach to planning emerged as the dominant one. It is argued that this is due, in large part, to Canada's unique character of economic development and class structure. Unlike countries, such as Britain, which developed more socialist modes of planning, urbanization in Canada was accompanied by a rapid expansion in agriculture and staple industries. Consequently, the Canadian response to development was logically divided between urban and rural concerns. Canada's industrial capitalist class and working class which were both promoting more aggressive urban planning were too weak to have much influence. The more powerful agrarian radicals and mercantile capitalists were able to direct attention away from the emerging urban problems to rural and resource issues which directly affected them.

In the end, the urban liberals were successful in resolving the conflict between urbanization and capitalist institutions. Limited acceptance of urban and regional planning allowed for the successful management of urban problems within the framework of capitalist institutions. Whether it will continue to be successful in doing this, only time will tell.

Elizabeth Bloomfield. "City-building Process in Berlin/ Kitchener and Waterloo, 1870-1930." Ph.D. Thesis, Department of History, University of Guelph, 1981.

This study of city-building processes in two Ontario industrial towns through the formative years of their development, 1870-1930, was prompted by the difficulty of explaining different rates of urban-industrial growth in cities with generally similar resources and accessibility. Selective growth clearly cannot be explained only by general impersonal forces and factors like centralization and metropolitan dominance, economies of scale, and location in relation to resources, transportation and markets. It is postulated that the collective determination of community leaders to advance their town was a powerful factor in its growth.

Berlin/Kitchener and Waterloo are considered good examples of the sub-metropolitan, industrial town, not yet adequately studied or understood, in which the interacting processes of urbanization and industrialization were worked out in the late nineteenth and early twentieth centuries. Berlin especially is an outstanding example of a lesser town with no natural advantages, which by determined effort and an industrial policy managed to become the leading city of its region by 1930 .

A detailed investigation of historical processes of urban economic development is the primary focus of the thesis, and general concepts of urban growth are blended with ideas on community structure and leadership, the urban ethos and municipal assistance to enterprises. Local entrepreneurs and élite groups made decisions and took actions to build up their cities according to their perceptions of the opportunities offered by the broader economic, technological and political forces of the time.

Two sets of city-building processes are discussed in detail - the economic and the spatial-environmental. The crucial importance of urban economic development to the city is demonstrated. Collective action to stimulate economic activity, notably by municipal inducements to manufacturers, was justified by the conviction that factories generated multiplier effects to benefit all sections of the community. In contrast, the processes by which the urban environment was shaped were left to private initiative, except in the planning movement after 1912 when there were again efforts to act collectively.

G. Drangushan. "Regional Planning in Alberta: The Evolution of Alberta's System of Regional Planning Commissions." M.A. Thesis, School of Community and Regional Planning, University of British Columbia, 1979.

Planning legislation in Alberta, particularly in the area of regional planning, has long been thought to be in the forefront of planning efforts in Canada. Alberta's experience has also been described as a lost opportunity, however, and with the enactment of Alberta's new Planning Act it is now appropriate to review the system of regional planning in Alberta. The objective of the thesis is to provide an understanding of the system of regional planning in Alberta by analyzing the structural evolution of the regional planning commission, the institution responsible.

In this study, a sequence of theoretical perspectives was identified including: regionalism (establishing the concept of regions and regional evolution and identifying centralizing and decentralizing strategies for government organization); regional planning (defining criteria for successful institutional arrangements for regional planning); and representation (providing a context for analysis of political representation of regional authorities). A description follows of the evolution of the regional planning commission system in the province, especially that of the Edmonton Regional Planning Commission, which was traced through the statutes, relevant literature and interviews with authorities and participants within the regional planning system in Alberta.

From the application of the theoretical perspectives, it was possible to assess the structure of the Alberta system and to generate some general observations on regional 
planning in that province. In addition, the theories themselves were reviewed for relevance in light of the thesis research.

D. Hinds. "The Evolution of Urban Public Park Design in Europe and America: Vancouver Adaptation to 1913." M.A. Thesis, School of Community and Regional Planning, University of British Columbia, 1979.

The nineteenth-century Victorian writer, John Ruskin, observed: "The measure of any great civilization is its cities; and the measure of a city's greatness is to be found in the quality of its public spaces - its parkland and squares." The objective of this thesis is to trace the origin, development and evolution of the design of the public park from the eve of the movement for such parks in Victorian England to the Vancouver park landscape in 1913. The identification and interpretation of historic design trends, social attitudes and regional influences on urban parks was based on a review of the literature on the history of the urban park in Europe and North America, starting in the eighteenth century, and a review of archival material from the Vancouver City Archives, contemporary literature and social histories of the city, and contemporary photographs of Vancouver's early parks.

The first parks in England that were originally designed for public use were largely the result of the negative effects of the industrial revolution and were developed in the north of England. The natural landscape design traditions already established for private estates, together with the desire to improve city living conditions, resulted in the naturalistic park, which was designed to enable people to "escape" back to nature. In London, where the effects of the industrial revolution on the landscape were not as evident, the existing royal parks were redesigned to provide for the citizens of western London. New parks were also created, particularly in the east end of London.

In the early nineteenth century, Georges Haussmann completely redesigned the central urban structure of Paris. He and Alphand used the English natural landscape park as a model for the Bois de Boulogne and the Bois de Vincennes, former royal hunting parks. Alphand also created numerous smaller parks and squares throughout the city which displayed very formal characteristics quite different from the British open-space system.

The Englishman's traditional love of the rural countryside was transferred across the Atlantic where Frederick Law Olmsted and his followers became the major exponents of this philosophy. The Americans' most significant contribution to the park movement was the development of park systems, which involved the integration of green space into the city structure. The French sense of civic pride and flair for formality surfaced in the United States at the end of the nineteenth century in the Beaux Arts inspired City Beautiful Movement, which influenced the design of the entrance to many parks and the manner in which parks were presented as an important component of the urban fabric.

In Canada, many cities inherited parklands from the federal government which were former defence posts or training grounds for the military. Canadians did not hire expert landscape architects to design these parks, and consequently their development was usually incremental. In Vancouver, the acquisition of Stanley Park, Vancouver's first and most important park, was a result of the availability of the Coal Peninsula military reserve. Hastings Park in 1888 was a grant from the provincial government, and Clark's Park was a gift to the city from a Toronto realtor in 1890. The desire simply to acquire land for park purposes was not to become prevalent in Vancouver for many years.

Between 1886 and 1913, the development of the Vancouver park landscape was largely influenced by three things: attitudes held by the people of Vancouver; ideas and influences from other places, primarily Britain and the American West Coast; and the social and political make-up of the community as manifested in various civic associations and ratepayers' groups.

The basic design features of Stanley Park were developed between 1886 and 1900 and included the park drive running around the periphery, the walking trails through the heart of the park, the Brockton Point Athletic fields, the relatively formal entrance to the park with the nearby zoo and the Second Beach bathing area. During the prosperous years from 1900 to 1913 , these features were further developed in the style that reflected the attitudes held by Vancouver's influential citizens. These years also saw the first major park expansion in Vancouver as the citizens supported the Park Board's deire to acquire land and ward ratepayers lobbied for neighbourhood parks. Similarly, the development of Second, English Bay and Kitsilano Beaches in the early 1900s and the creation of supervised children's playgrounds in the 1920s happened only after particular groups provided the impetus for these facilities.

In 1913, Vancouver had an expanding and pleasing park system - but a system that had luckily experienced positive incremental development. Although the Park Board lacked a development policy for Vancouver's parks, the citizens' instinctive desire for naturalistic parks guided the park system through the initial years of development and managed to overcome a major threat to the natural integrity of Stanley Park. 
S.L. Kelly. "Senior Citizen Housing in Edmonton: A Spatial Perspective." M.A. Thesis, Department of Geography, University of Alberta, 1980.

Until recently, research into the housing needs of the elderly has been conducted by social gerontologists, sociologists and other social scientists from an aspatial perspective. Their work has focused on the socio-psychological impact of housing design and on the need to provide housing for the growing numbers of elderly poor. Such studies have neglected spatial or environmental factors, however, and, more particularly, they have not considered how elderly people interact with their environment beyond the confines of their place of residence.

Public housing authorities must weigh a number of important factors in selecting sites for senior citizen housing projects. The availability of capital, suitable sites and sponsors for the project and the prevailing political climate in the host neighbourhood are good examples of these concerns. Ultimately, however, it is the project's location with respect to family, friend and to desired amenities and services that is important for those who live there. This thesis examines this problem from the latter perspective.

The city of Edmonton, where the study was conducted, has a relatively low elderly population compared to other Canadian cities; however, the city exhibits an aging trend not dissimilar to that of the province of Alberta or the nation as a whole. Analysis of housing registry waiting lists of the Society for the Retired and Semi-Retired provided insight into the socio-economic and spatial preferences of elderly people who have applied for senior citizen housing. Demand for housing was high among single women, and among renters. Unlike the results of most other studies, the registrants' preferences for future housing location appeared to hinge on a single factor: they wished to remain on the same side of the North Saskatchewan River as they then lived.

At the neighbourhood level, low rent and proximity to bus service and shopping were cited by residents of two senior citizen housing projects as important factors in choosing senior citizen housing. Proximity to a major chain grocery store and to a regional shopping centre proved to be major determinants of neighbourhood satisfaction among the respondents. Other neighbourhood characteristics went unnoticed by the majority of those interviewed.

Since this study represents a beginning to the analysis of the qualitative aspects of senior citizen housing location, several avenues for additional research have been identified throughout the course of the thesis.
R.G.F. Higgings. "The Role of the State in the Development of Town Planning in England, 1875-1909." M.A. Thesis, Department of Geography, University of Alberta, 1980.

The establishment of town planning as a state activity in Britain, as signified by the Housing, Town Planning, etc. Act of 1909, is generally and uncritically seen as the beginning of a new social reform movement advancing freedom and democracy. But this conception of planning has been severely questioned. Little attempt has been made to explain how the conception of planning as a new social movement evolved from the mid-nineteenth century utilitarian beginnings of state intervention in the urban environment. In 1875, the first clearly recognizable example of town-planning legislation was enacted. From this date, the state increasingly intervened in private rights regarding the physical environment in the name of the public welfare. This thesis examines the evolving legislation and the surrounding parliamentary debates in terms of the debate on planning and freedom.

From 1875, the legislation furthered the power of the state over private rights; it increased centralization and the power of the non-elected official even though this development conflicted with prevailing conceptions of individual and political freedom. The key factor impelling this change was the adherence to the utilitarian ethic which conceived the public welfare in terms of efficiency. This was the ethic on which the act of 1909 was based. The act signified no break with the utilitarian tradition of reform. Indeed, the utilitarian ethic has continued to guide the operation of town planning to this day.

Sara D.S. Gibson, "Sense of Place - Defence of Place: A Case Study of the Toronto Island." Ph.D. Thesis, Department of Geography, University of Toronto, 1981.

This thesis investigates the dialectical relationship between sense of place (a feeling of belonging in and having a deep emotional attachment to a place of personal significance and meaning) and defence of place (specific political, legal and other actions taken to protect a place that is threatened). When a place to which a person or a group of people is srongly attached is threatened in some way, the sense of place may lead to and condition the nature of the defence of place; similarly, when a place is threatened and defended, that defence of place in turn conditions and influences the nature of sense of place. In this dialectical relationship, the concept of threat occupies a position of central importance as a catalyst to action and a continuing influence.

The phenomenon of sense of place may exist in the absence of a severe threat or any defence of place. But when 
defence of place is evident, sense of place is the foundation upon which it is built. Sense of place, therefore, is of primary importance in this investigation. It is argued that sense of place is a subjective phenomenon and, based on the information collected for this study, that it is composed of six interrelated components: sense of history, sense of identity, sense of community, sense of environment, sense of control and sense of change.

Because of the nature of sense of place, this study adopts as much as possible an experiential perspective; that is, it attempts to understand the phenomena of sense of place and defence of place from the perspective of the individuals involved, using their own words and actions as clues to how they relate to their particular place. In order to explore the complex, holistic, multi-faceted nature of sense of place and its relation to defence of place, this study presents a detailed, case study of a particular group of individuals (Toronto Islanders) and how they have related to a particular place (Toronto Island), which has been subjected to a variety of threats over a long period of time. In order to accomplish these ends, a variety of data sources and techniques were employed, most notably a lengthy period of participant observation (which involved living on the Island for approximately four months and extensive visiting over a period of six years) and interviewing of both Islanders (over eighty hours of taped interviews) and politicians (over twenty hours of taped interviews). In addition, the voluminous documentary records were analyzed.

Evidence is presented that Toronto Islanders have experienced a sense of place and have repeatedly defended their special place against outside threats to alter radically or to destroy it. By devoting one chapter to each of the six major components of sense of place, this study defines each, provides copious evidence that Toronto Islanders have experienced each one, analyzes the Island and Islanders in terms of each component and analyzes the dialectical links between each component and defence of place. This study, therefore, also demonstrates (by constant reference to detailed observations and comments from individual Islanders) how each general component of sense of place may be applied and analyzed in a particular place and may serve as a guide to future studies.

Irene E. Robertson. "The Business Community and the Development of Victoria, 1858-1900." M.A. Thesis, Department of History, University of Victoria, 1981.

This thesis examines the role Victoria's business community played in the evolution of the city from fur-trade post to metropolitan centre and in its subsequent decline as an entrepôt of provincial significance. During the years 1858 to 1900 , a distinct group of businessmen emerged in Victoria, and their achievements and contributions to the city are related to its overall development and in this study.

Wholesale-retail and commission merchants formed the nucleus of the business community during the goldrush era, which capitalized on a maritime trade connection with British-based companies in San Francisco. During the decade 1880-90, these merchants broadened their interests to include real estate, mining, sealing and salmon canning. Reflecting the commercial interests of the business community throughout this period was the British Columbia Board of Trade. Its activities are examined to illustrate the collective aspirations of merchant entrepreneurs and the economic influence they exerted upon the city.

Businessmen were also actively involved in municipal, provincial and, to some degree, national politics. Their participation in local government is studied to ascertain to what extent merchants influenced the evolution of Victoria, especially in providing utility services. Culturally, businessmen represented a major force in the social life of the city. This was particularly true during the period 1880-90, when social recognition resulted from commercial success. Contributions to the cultural development of Victoria and participation in civic organizations are identified as important indicators of wealth and prestige. An examination of cultural activities also helps to identify some of the unique attributes of this group of individuals.

External factors also affected the degree to which businessmen influenced the development of Victoria. For example, during the period 1858-64, Governor James Douglas initiated policies that promoted Victoria over its mainland rival, New Westminster. Moreover, during the gold-rush, Victoria's commercial superiority was assured by virtue of its geographical location and established trading patterns. In this context the inability of merchants to halt Victoria's decline between 1890 and 1900 is examined. During this period Vancouver, which became the terminus of the Canadian Pacific Railway, replaced Victoria as the major commercial centre in British Columbia.

Finally, this study of the Victoria business community is placed in the general context of Canadian urban studies and provides a basis for further comparative research. Similarities and differences between the merchants of Victoria and those of other cities, such as Winnipeg, Toronto and Vancouver, are noted in order to determine the degree to which the experience of the business community in Victoria was unique. 